posals for recombinant DNA research to ensure that they would comply with the NIH guidelines, maintaining links with the biohazards committees at Harvard and MIT, and "developing a procedure for members of institutions where the research is carried out to report to the $C B C$ violations either in technique or established policy".

In addition, the committee urged Congress to pass legislation extending the NIH guidelines to cover all recombinant DNA research in the United States and to set up a national registry of laboratory workers for long term epidemiological studies.

The report has been welcomed by supporters of the research. David Baltimore, a tumour virologist at MIT's Cancer Research Center, said in an interview last week that the report "is basically a vindication of the whole process which began with the NAS committee", which raised the first concerns about the potential hazards associated with the research.

Opponents of the research are dis- appointed that the committee didn't come down in favour of banning the research in Cambridge, but they also agree with much of the report. In particular, Jonathan King, an MIT biologist who has been among the more outspoken opponents, noted in an interview that creation of the $C B C$ would be a good step toward more citizen control over research and it would lead to increased accountability of scientists to the public. He also welcomed the suggestion that the health of laboratory workers be monitored, but suggested that unless pressed the universities would drag their feet in implementing the recommendation.

The ball is now back in the City Council's court. At the meeting on January 5 when the report was publicly unveiled, the council passed a resolution extending the moratorium on P3-level experiments in Cambridge for a further 30 days to allow time to consider the recommendations and to hear responses from the universities. Vellucci has promised to introduce a resolution banning $\mathrm{P} 3$ - and $\mathrm{P} 4-\mathrm{level}$ experiments entirely and making scientists who conduct such rescarch liable for a fine of $\$ 1000$ per day. Another resolution will be proposed to implement the committee's report.

One Cambridge Councillor, David Clem, said last week that he expects the report to be well received, and that the matter will probably be cleared up before the extended moratorium is scheduled to end. He noted, however, that he has some reservations about the recommendations and will wait to see what plans the universities have for implementing them before he decides how to vote.

Finally, it should be noted that other local governments, particularly the New York Attorney General's office, are taking a close look at the control of recombinant DNA research. The fact that a committee of non-scientists has recommended in favour of going ahead with the research, albeit under strict controls, will not pass unnoticed.

\title{
PAKISTAN
}

\section{New policy on the anvil}

Asim Kidwai reports from Karachi on changes expected in Pakistan's science policy framework

THE economic, social and cultural changes that have occurred under the Bhutto government-they include nationalisation of almost all domestic banks and insurance companies, of the heavy industrial and parts of the agricultural sector, but not consumer goods industries like textiles, tobacco, chemicals and pharmaceuticals-have naturally had an impact on science policy. A new national policy now on the anvil is the result of lengthy deliberations amongst the clite of the scientific community and representatives of various scientific organisations and government agencics. Final proposals are expected once they have been discussed it (abinet level.

The existing arrangements for scientific and technological research in Pakistan appear to suffer from three weaknesses: coordination of effort at national level is lacking; the universities have a very weak base as far as scientific research goes; and no effective mechanism exists for the utilisation of the results of research. At the apex of the structure of science in Pakistan lies the Ministry of Science \& Technology of the central government assisted by the National Science Council and the Pakistan Science Foundation.
The National Science Council was created as a coordinating body for the different Research Councils and to advise the government on promotion of science in general, but in practice rarely discharged those functions effectively, possibly because it had no financial or budgetary strings to pull. It thus remained but a shadow of what it was originally conceived to be. The Pakistan Science Foundation was created subsequently as a sponsoring body to help promote financial support for university research work and promising individual research workers, for pilot plant studies, for the establishment of science museums and for scientific societics. This it has been doing within the limits imposed by the funds at its disposal.

This triangle at the top lacked coordination, and in practice was not up to implementing a vigorous science policy fully integrated into the national development effort. Suitably informed decisions could not be made at the top political level, and administrative coordination was inadequate, particularly in respect of planning. The proposals for the new science policy try to take account of these weaknesses. A National Council for Science and Technology is proposed is the supreme body to provide guidance on all matters pertaining to formulation and implementation of government policy on science and technology. It should also be responsible for planning, coordination and cooperative imple- mentation of scientific and technological programmes. The proposed National Council may be headed by the Prime Minister, and the central ministry for science is to act as its secretariat.

The Research Councils-the Pakistan Council of Scientific and Industrial Research, Pakistan Medical Research Council, Irrigation. Drainage and Flood Control Research Council, Council for Works and Housing Research, Agricultural Research Council and the recently approved Livestock Research Council-are likely to be given autonomous character and resources to organise mission-oriented research in their specialised fields.

Some idea of the scope of R\&D effort through these institutions can be gained from the budget figures for the current year, which reflect to some extent their relative weaknesses and strength. These are shown in the accompanying table.

Pakistan's science rescarch budget 1976-77

Council Rupees

Scientific \& Technological Research Division of the Ministry

National Science Council

Pakistan Science Foundation

Pakistan Council of Scientific and Industrial Research

Pakistan Medical Research Council

$1,998,000$ 443,000

$5,500,000$

Irrigation, Drainage and

Flood Control Council

Council for Works and

Hnusing Research

29.320 .000

$1,506,000$

740,000

$£ 1=16.5$ Pakistani rupees 